\title{
Analisa Hidrologi Untuk Penentuan Metode Intensitas Hujan Di Wilayah Aerocity X
}

\author{
Linda Aslyah Febriani ${ }^{1}$, Eka Wardhani ${ }^{1}$, Nico Halomoan ${ }^{1}$ \\ ${ }^{1}$ Jurusan Teknik Lingkungan, Fakultas Teknik Sipil dan Perencanaan, Institut Teknologi Nasional, Jln.PHH. \\ Mustopha No.23 - Bandung 40124. Telp: (022)7272215. Email :lindaaslyah@gmail.com
}

\begin{abstract}
Abstrak
Penelitian ini dilakukan untuk mengetahui besarnya Intensitas Hujan di kawasan Aerocity X yang kemudian akan dipakai untuk penentuan dimensi saluran drainase di Aerocity X. Intensitas hujan adalah jumlah curah hujan yang dinyatakan dalam tinggi hujan atau volume hujan persatuan waktu. Besarnya intensitas curah hujan berbeda-beda tergantung dari lamanya curah hujan dan frekuensi kejadian. Intensitas curah hujan ini sangat penting untuk perencanaan debit banjir rencana. Perhitungan dilakukan menggunakan data curah hujan yang terdapat pada pos pengamatan hujan disekitar Aerocity X, yaitu pos hujan Pakubeureum TAMBEN, Jatiwangi TAMBEN, dan Kadipaten TAMBEN. Nilai intensitas hujan didapatkan dengan mengubah data curah hujan harian maksimum menggunakan metoda statistik yang umum digunakan dalam aplikasi hidrologi, yaitu metode Van Breen, Bell Tanimoto, dan Hasper Der Weduwen. Besarnya intensitas hujan yang diperoleh di subtitusikan kedalam rumus Talbot, Sherman, dan Ishiguro dan dibandingkan dengan harga intensitas hujan awal kemudian dipilih metode yang mempunyai nilai standar deviasi terkecil. Hasil perhitungan menunjukan bahwa metode intensitas hujan yang terpilih adalah Metode Van Breen dengan Persamaan Talbot denganPUH 2, 5, 10, 25, 50 dan 100 tahun.
\end{abstract}

Kata Kunci: Debit Banjir, Intensitas Hujan, Standar Deviasi.

\begin{abstract}
This research was conducted to determine the magnitude of Rain Intensity in the Aerocity X region which will then be used to determine the dimensions of drainage channels in Aerocity X. Rain intensity is the amount of rainfall expressed in terms of rainfall height or rainfall volume per unit time. The amount of rainfall intensity varies depending on the length of rainfall and the frequency of occurrence. The intensity of rainfall is very important for planning flood discharge plans. Calculations are made using rainfall data contained at the rain observation post around Aerocity X, namely Pakubeureum TAMBEN, Jatiwangi TAMBEN, and Kadipaten TAMBEN. Rain intensity values are obtained by changing the maximum daily rainfall data using statistical methods commonly used in hydrological applications, namely the Van Breen, Bell Tanimoto, and Hasper Der Weduwen methods. The amount of rainfall intensity obtained is substituted into the Talbot, Sherman, and Ishiguro formulas and compared with the initial rainfall intensity price then the method that has the smallest standard deviation is selected. The calculation results show that the rain intensity method chosen is the Van Breen Method with the Talbot Equation for the PUH 2, 5, 10, 25, 50 and 100 years.
\end{abstract}

Keywords:Flood Discharge, Rain Intensity, Standard Deviation.

\section{PENDAHULUAN}

Kawasan Aerocity X terletak di Kecamatan Kertajati dengan luas total sebesar 3.480 Ha. Rencana pembangunan Aerocity X ini tercantum dalam Peraturan Daerah Kabupaten Majalengka Nomor 11 Tahun 2011, dalam peraturan tersebut disebutkan bahwa terdapat kawasan yang diperuntukan untuk Bandara Internasional Jawa Barat dan Aerocity X.Aerocity X merupakan konsep pengembangan Kota Bandara atau Airport City atau istilah yang saat ini dikenal dengan sebutan Aetropolis. Adanya pengembangan Aerocity X ini 
dapat memicu peningkatan kegiatan bisnis yang dapat mengubah lahan yang sebelumnya merupakan lahan hijau untuk penyerapan air menjadi kawasankawasan usaha dan industri, sehingga potensi terjadinya banjir pada saat musim hujan cukup besar.

Perencanaan drainase memerlukan analisa hidrologi. Data hidrologi dianalisis untuk membuat keputusan dan menarik kesimpulan mengenai fenomena hidrologi berdasarkan sebagian data hidrologi yang dikumpulkan (Soewarno,1995). Penentuan nilai intensitas hujan diperlukan untuk mendapatkan nilai debit banjir rencana pada wilayah perencanaan.

Nilai intensitas hujan ini akan menentukan tingginya hujan per satuan waktu. Data curah hujan harian maksimum yang didapat dari pos pengamat hujan utama yaitu pos Pakubeureum TAMBEN merupakan data dasar dalam penentuan nilai intensitas hujan.

Penentuan nilai intensitas hujan didapatkan dengan menggunakan metode Van Bren, Bell Tanimoto dan Hasper Der Weduwen. Besarnya intensitas setiap metode tersebut disubstitusikan kedalam persamaan Talbot, Sherman dan Ishiguro. Metode intensitas hujan yang dipilih dengan melihat nilai standar deviasi terkecil.

\section{METODE}

Diagram Alir metode penentuan intensitas hujan dapat dilihat pada Gambar 1.

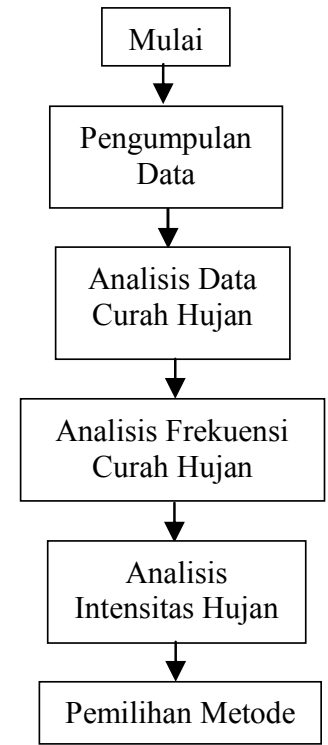

Gambar 1. Diagram Alir Penentuan Metode Intensitas Hujan

\section{Pengumpulan Data}

Data yang diperlukan untuk penentuan metode intensitas hujan adalah data curah hujan dari stasiun hujan yang berada di wilayah perencanaan. Data curah hujan didapatkan dari Pusat Penelitian dan Pengembangan Sumber Daya Air (Pusair) di kota Bandung. Data curah hujan yang diperlukan adalah data curah hujan selama 30 tahun yang berasal dari pos hujan Pakubeureum TAMBEN, Jatiwangi TAMBEN, dan Kadipaten TAMBEN.

\section{HASIL DAN PEMBAHASAN}

Data curah hujan yang digunakan merupakan data curah hujan harian maksimum selama 30 tahun dari tahun 1988 sampai 2017, yang diperoleh dari pos hujan terdekat dengan Aerocity X, yaitu Pakubeureum TAMBEN, Kadipaten TAMBEN dan Jatiwangi TAMBEN. Data curah hujan dapat dilihat pada Tabel 1.

Tabel 1. Data Curah Hujan Harian Maksimum

\begin{tabular}{|c|c|c|c|c|}
\hline \multirow[b]{2}{*}{ No } & \multirow[b]{2}{*}{ Tahun } & \multicolumn{3}{|c|}{ Curah Hujan Maksimum Pertahun } \\
\hline & & $\begin{array}{c}\text { Pos } \\
\text { Pakubeureum } \\
\text { TAMBEN }\end{array}$ & $\begin{array}{c}\text { Pos } \\
\text { Kadipaten } \\
\text { TAMBEN }\end{array}$ & $\begin{array}{c}\text { Pos } \\
\text { Jatiwangi } \\
\text { TAMBEN }\end{array}$ \\
\hline 1 & 1988 & - & 150 & - \\
\hline 2 & 1989 & - & 150 & - \\
\hline 3 & 1990 & - & 147 & - \\
\hline 4 & 1991 & - & 91 & - \\
\hline 5 & 1992 & 170 & 116 & 130 \\
\hline 6 & 1993 & 176 & 75 & 187 \\
\hline 7 & 1994 & 170 & 104 & 187 \\
\hline 8 & 1995 & 145 & 98 & 125 \\
\hline 9 & 1996 & 74 & 146 & 128 \\
\hline 10 & 1997 & 96 & 105 & 84 \\
\hline 11 & 1998 & 112 & 90 & 134 \\
\hline 12 & 1999 & 127 & 126 & 113 \\
\hline 13 & 2000 & 74 & 72 & 125 \\
\hline 14 & 2001 & 130 & 131 & 87 \\
\hline 15 & 2002 & 104 & 207 & 71 \\
\hline 16 & 2003 & 108 & 75 & 135 \\
\hline 17 & 2004 & 202 & 75 & 195 \\
\hline 18 & 2005 & 118 & - & 120 \\
\hline 19 & 2006 & 166 & - & - \\
\hline 20 & 2007 & - & - & 95 \\
\hline 21 & 2008 & 102 & 75 & 60 \\
\hline 22 & 2009 & 108 & 74 & - \\
\hline 23 & 2010 & 118 & 76 & 126 \\
\hline 24 & 2011 & 96 & 76 & 95 \\
\hline 25 & 2012 & - & 76 & - \\
\hline 26 & 2013 & - & - & 114 \\
\hline 27 & 2014 & 69 & - & 145 \\
\hline 28 & 2015 & 72 & - & 94,6 \\
\hline 29 & 2016 & 60 & - & 173,16 \\
\hline 30 & 2017 & 103 & 223 & 173,16 \\
\hline \multicolumn{2}{|c|}{ Jumlah } & 2.700 & 2.558 & 289,92 \\
\hline \multicolumn{2}{|c|}{ Rata-rata } & 117,39 & 111,22 & 125,95 \\
\hline
\end{tabular}

Sumber: Pusair Kota Bandung, 2019

Berdasarkan Tabel 1, terdapat data curah hujan yang hilang. Menurut Prawaka (2016), kehilangan data tersebut disebabkan oleh kelalaian dari petugas

Proteksi/Desember 2019 Volume 1 No. 2 
pencatat curah hujan atau rusaknya alat pencatat curah hujan karena kurangnya perawatan, untuk melengkapi data yang hilang dapat menggunakan metode Aljabar dan Perbandingan Normal.

\section{Analisis Data Curah Hujan}

Dalam analisis data curah hujan dilakukan beberapa tahap, yaitu:

\section{a. Penentuan Stasiun Utama}

Penentuan stasiun utama dipilih menggunakan metode Polygon Thiesen karena cocok dengan kondisi eksisting daerah perencanaan, yaitu stasiun yang memiliki jarak berbeda antar stasiunnya (Suripin,2004). Hasil metode Polygon Thiesen dapat dilihat pada Gambar 2.

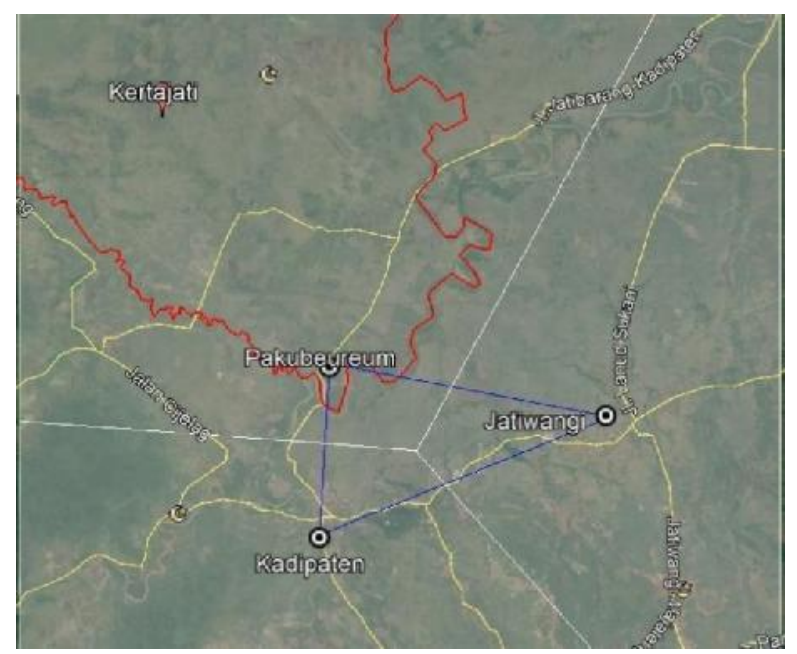

Gambar 2. Polygon Thiessen (sumber: Google Earth, 2019)

Berdasarkan Gambar 2., Pos Pakubeureum TAMBEN terpilih menjadi stasiun utama karena luasan daerah pengaruhnya mendominasi wilayah perencanaan serta pos Kadipaten TAMBEN dan pos Jatiwangi TAMBEN menjadi stasiun pembanding, sehingga untuk perhitungan selanjutnya menggunakan data tersebut.

\section{b. Pelengkapan Data Curah Hujan}

Penentuan metode pelengkapan data curah hujan yang hilang dilakukan dengan menggunakan Persamaan [1]. Berdasarkan hasil perhitungan, perbedaan data curah antar stasiun kurang dari $10 \%$, maka metode Aljabar yang dipilih. Hasil kelengkapan data curah hujan dapat dilihat pada Tabel 2.
Tabel 2. Kelengkapan Data Curah Hujan

\begin{tabular}{|c|c|c|c|c|}
\hline \multirow[b]{2}{*}{ No } & \multirow[b]{2}{*}{ Tahun } & \multicolumn{3}{|c|}{ Curah Hujan Maksimum Pertahun } \\
\hline & & $\begin{array}{c}\text { Pos } \\
\text { Pakubeureum } \\
\text { TAMBEN }\end{array}$ & $\begin{array}{c}\text { Pos } \\
\text { Kadipaten } \\
\text { TAMBEN }\end{array}$ & $\begin{array}{c}\text { Pos } \\
\text { Jatiwangi } \\
\text { TAMBEN }\end{array}$ \\
\hline 1 & 1988 & 50 & 150 & 50 \\
\hline 2 & 1989 & 50 & 150 & $\mathbf{5 0}$ \\
\hline 3 & 1990 & 49 & 147 & 49 \\
\hline 4 & 1991 & 30 & 91 & 30 \\
\hline 5 & 1992 & 170 & 116 & 130 \\
\hline 6 & 1993 & 176 & 75 & 187 \\
\hline 7 & 1994 & 170 & 104 & 187 \\
\hline 8 & 1995 & 145 & 98 & 125 \\
\hline 9 & 1996 & 74 & 146 & 128 \\
\hline 10 & 1997 & 96 & 105 & 84 \\
\hline 11 & 1998 & 112 & 90 & 134 \\
\hline 12 & 1999 & 127 & 126 & 113 \\
\hline 13 & 2000 & 74 & 72 & 125 \\
\hline 14 & 2001 & 130 & 131 & 87 \\
\hline 15 & 2002 & 104 & 207 & 71 \\
\hline 16 & 2003 & 108 & 75 & 135 \\
\hline 17 & 2004 & 202 & 75 & 195 \\
\hline 18 & 2005 & 118 & 119 & 120 \\
\hline 19 & 2006 & 166 & 55 & 55 \\
\hline 20 & 2007 & 32 & 32 & 95 \\
\hline 21 & 2008 & 102 & 75 & 60 \\
\hline 22 & 2009 & 108 & 74 & 91 \\
\hline 23 & 2010 & 118 & 76 & 126 \\
\hline 24 & 2011 & 96 & 76 & 95 \\
\hline 25 & 2012 & 25 & 76 & 25 \\
\hline 26 & 2013 & 38 & 38 & 114 \\
\hline 27 & 2014 & 69 & 71 & 145 \\
\hline 28 & 2015 & 72 & 56 & 94.6 \\
\hline 29 & 2016 & 60 & 78 & 173,16 \\
\hline 30 & 2017 & 103 & 223 & 173,16 \\
\hline
\end{tabular}

Data curah hujan yang sudah lengkap di setiap pos hujan kemudian dilakukan uji konsistensi untuk mengetahui kekonsitenan data.

\section{c. Uji Konsistensi}

Uji konsistensi dilakukan untuk mengetahui data curah hujan hasil analisis mendekati kenyataan sehingga kesalahan perencanaan dapat di minimalisir. Ketidakkonsistenan sekumpulan data dapat disebabkan oleh:

- Perubahan tata guna lahan pada DAS dan sekitarnya;

- Perpindahan tempat/lokasi stasiun pengukur;

- Perubahan ekosistem terhadap iklim, misal: kebakaran hutan, tanah longsor; dan

- Terdapatnya kesalahan sistem observasi data pada sekumpulan data hujan.

Uji konsistensi dilakukan denganp analisis kurva masaa ganda menggunakan data akumulasi hujan tahunan.Langkah-langkah dalam menentukan uji konsistensi adalah (Meilinda,2007):

- Seleksi data stasiun hujan, pos hujan Pakubeureum TAMBEN merupakan stasiun utama berdasarkan metode Polygon Thiessen, Proteksi/Desember 2019 Volume 1 No. 2 
pos Kadipaten TAMBEN dan Jatiwangi TAMBEN merupakan stasiun pembanding .

- Data dari seluruh stasiun utama dan pembanding di rata-ratakan kemudian diakumulasikan dari tahun awal pengamatan.

- Titik akumulasi stasiun utama dan pembanding di plotkan pada kurva massa ganda. Data tidak mengikuti trend dimulai dari tahun 2017. Oleh karena itu perlu dilakukan koreksi sehingga trend yang akan datang akan mengikuti trend yang baru, berdasarkan hasil perhitungan didapatkan nilai faktor koreksi yaitu 1,0791. Data curah hujan pada stasiun utama kemudian dikalikan dengan faktor koreksi. Rekapitulasi hasil koreksi curah hujan dapat dilihat pada Tabel 3.

Tabel 3. Rekapitulasi Curah Hujan Hasil Koreksi

\begin{tabular}{|c|c|c|c|}
\hline No & Tahun & Curah Hujan & $\begin{array}{c}\text { Curah Hujan Hasil } \\
\text { Koreksi }\end{array}$ \\
\hline 1 & 1988 & 50 & 54 \\
\hline 2 & 1989 & 50 & 54 \\
\hline 3 & 1990 & 49 & 53 \\
\hline 4 & 1991 & 30 & 33 \\
\hline 5 & 1992 & 170 & 183 \\
\hline 6 & 1993 & 176 & 190 \\
\hline 7 & 1994 & 170 & 183 \\
\hline 8 & 1995 & 145 & 156 \\
\hline 9 & 1996 & 74 & 80 \\
\hline 10 & 1997 & 96 & 104 \\
\hline 11 & 1998 & 112 & 121 \\
\hline 12 & 1999 & 127 & 137 \\
\hline 13 & 2000 & 74 & 80 \\
\hline 14 & 2001 & 130 & 140 \\
\hline 15 & 2002 & 104 & 112 \\
\hline 16 & 2003 & 108 & 117 \\
\hline 17 & 2004 & 202 & 218 \\
\hline 18 & 2005 & 118 & 127 \\
\hline 19 & 2006 & 166 & 179 \\
\hline 20 & 2007 & 32 & 34 \\
\hline 21 & 2008 & 102 & 110 \\
\hline 22 & 2009 & 108 & 117 \\
\hline 23 & 2010 & 118 & 127 \\
\hline 24 & 2011 & 96 & 104 \\
\hline 25 & 2012 & 25 & 27 \\
\hline 26 & 2013 & 38 & 41 \\
\hline 27 & 2014 & 69 & 74 \\
\hline 28 & 2015 & 72 & 78 \\
\hline 29 & 2016 & 60 & 65 \\
\hline 30 & 2017 & 103 & 111 \\
\hline
\end{tabular}

Sumber: Hasil Perhitungan, 2019

Perhitungan yang digunakan untuk uji homogenitas menggunakan data yang sudah di koreksi yang terdapat pada Tabel 3.

\section{d. Uji Homogenitas}

Uji homogenitas ini dilakukan pada kurva uji homogenitas dengan mengeplotkan titik $\mathrm{H}$ $\left(\mathrm{N}, \mathrm{T}_{\mathrm{R}}\right)$ pada kertas grafik. Data curah hujan dikatakan homogen jika titik $\mathrm{H}\left(\mathrm{N}, \mathrm{T}_{\mathrm{R}}\right)$ berada pada corong kurva. Data awal yang akan digunakan dalam uji homogenitas dapat dilihat pada Tabel 4 .

Tabel 4. Data Awal Uji Homogenitas

\begin{tabular}{|c|c|c|c|c|c|}
\hline No & Tahun & $\begin{array}{l}\text { Curah } \\
\text { Hujan }\end{array}$ & $\mathrm{Ri}$ & Ri-命 & $(\mathrm{Ri}-\overline{\mathrm{R}})^{2}$ \\
\hline 1 & 1988 & 50 & 27 & -80 & 6.344 \\
\hline 2 & 1989 & 50 & 33 & -74 & 5.514 \\
\hline 3 & 1990 & 49 & 34 & -73 & 5.302 \\
\hline 4 & 1991 & 30 & 41 & -66 & 4.354 \\
\hline 5 & 1992 & 170 & 53 & -54 & 2.928 \\
\hline 6 & 1993 & 176 & 54 & -53 & 2.812 \\
\hline 7 & 1994 & 170 & 54 & -53 & 2.812 \\
\hline 8 & 1995 & 145 & 65 & -42 & 1.784 \\
\hline 9 & 1996 & 74 & 74 & -33 & 1.058 \\
\hline 10 & 1997 & 96 & 78 & -29 & 858 \\
\hline 11 & 1998 & 112 & 80 & -27 & 736 \\
\hline 12 & 1999 & 127 & 80 & -27 & 736 \\
\hline 13 & 2000 & 74 & 104 & -3 & 12 \\
\hline 14 & 2001 & 130 & 104 & -3 & 12 \\
\hline 15 & 2002 & 104 & 110 & 3 & 9 \\
\hline 16 & 2003 & 108 & 111 & 4 & 17 \\
\hline 17 & 2004 & 202 & 112 & 5 & 27 \\
\hline 18 & 2005 & 118 & 117 & 10 & 91 \\
\hline 19 & 2006 & 166 & 117 & 10 & 91 \\
\hline 20 & 2007 & 32 & 121 & 14 & 192 \\
\hline 21 & 2008 & 102 & 127 & 20 & 414 \\
\hline 22 & 2009 & 108 & 127 & 20 & 414 \\
\hline 23 & 2010 & 118 & 137 & 30 & 904 \\
\hline 24 & 2011 & 96 & 140 & 33 & 1.109 \\
\hline 25 & 2012 & 25 & 156 & 49 & 2.449 \\
\hline 26 & 2013 & 38 & 179 & 72 & 5.205 \\
\hline 27 & 2014 & 69 & 183 & 76 & 5.846 \\
\hline 28 & 2015 & 72 & 183 & 76 & 5.846 \\
\hline 29 & 2016 & 60 & 190 & 83 & 6.878 \\
\hline 30 & 2017 & 103 & 218 & 111 & 12.319 \\
\hline \multicolumn{2}{|c|}{ Rata-rata } & 107 & & & \\
\hline \multicolumn{2}{|c|}{ SD } & 51,55 & & & \\
\hline
\end{tabular}

Sumber: Hasil Perhitungan, 2019

Data yang digunakan adalah data curah hujan selama 30 tahun, maka $\mathrm{n}=30$. Penentuan nilai Yn=0,536 dilihat pada tabel Reduce Mean dan nilai $\mathrm{Sn}=1,1124$ dilihat dari tabel Reduce Standar Deviation. Penentuan nilai tinggi hujan menggunakan persamaan $\mathrm{R}_{\mathrm{T}}=83,81+40,21 \mathrm{Y}_{\mathrm{T}}$ dengan nilai $\mathrm{Y}_{\mathrm{T}}=3,38$. Penentuan nilai $1 / \alpha$ dihitung dengan menggunakan data Standar Deviasi dan Sn, sehingga didapatkan 46,34. Data-data tersebut digunakan untuk menghitung nilai $\mathrm{R}_{0}$ dan $\mathrm{R}_{5}$.

Nilai $R_{0}$ dan $R_{5}$ dicari untuk menentukan titik $\mathrm{D}$ dan $\mathrm{G}$, berdasarkan hasil perhitungan didapat titik $\mathrm{D}\left(\mathrm{Y}_{0}: \mathrm{R}_{0}\right)=\mathrm{D}(0: 82)$ dan $\mathrm{G}\left(\mathrm{Y}_{5}: \mathrm{R}_{5}\right)=\mathrm{G}$ (5:314). Titik D dan G kemudian di plotkan ke dalam kertas Gumble Probability Extreme untuk menentukan nilai $T_{R}$ (grafik).Hasil plot nilai $T_{R}$ $($ grafik $)=2,9$. 
Penentuan nilai $T_{R}$ yang akan di plotkan ke grafik uji homogenitas ditentukan dengan menggunakan Persamaan [4]. Hasil perhitungan didapatkan nilai $T_{R}$ yaitu 6 , sehingga titik $\mathrm{H}\left(\mathrm{N}: \mathrm{T}_{\mathrm{R}}\right)$ yaitu $\mathrm{H}(30: 6)$.

Titik tersebut kemudian di plotkan pada kertas grafik uji homogenitas. Hasil plot, titik $\mathrm{H}(30: 6)$ berada didalam cekungan grafik homogenitas yang menunjukkan bahwa data homogen, sehingga perhitungan dapat dilanjutkan untuk mencari analisa frekuensi curah hujan.

\section{Analisis Frekuensi Curah Hujan}

Penentuan analisa frekuensi curah hujan terdiri dari:

\section{a. Metode Gumbel}

Data awal yang digunakan dapat dilihat pada Tabel 5 .

Tabel 5. Data Awal Metode Gumble

\begin{tabular}{cc}
\hline Keterangan & Nilai \\
\hline $\mathrm{R}$ & 107 \\
\hline $\mathrm{SD}$ & 51,55 \\
\hline $\mathrm{n}$ & 30 \\
\hline $\mathrm{Yn}$ & 0,536 \\
\hline $\mathrm{Sn}$ & 1,1124 \\
\hline $1 / \alpha$ & 46,34 \\
\hline
\end{tabular}

Sumber: Hasil Perhitungan,2019

Penentuan curah hujan berdasarkan metode Gumbel didapatkan dengan menggunakan Persamaan [5]. Rekapitulasi hasil perhitungan curah hujan harian maksimum dengan menggunakan Metode Gumbel dapat dilihat padaTabel 6 .

Tabel 6. Rekapitulasi Curah Hujan Metode Gumbel

\begin{tabular}{cccc}
\hline No & PUH & Yt & $\mathrm{R}_{\mathrm{T}}$ \\
\hline 1 & 2 & 0,367 & 99,133 \\
\hline 2 & 5 & 1,500 & 151,661 \\
\hline 3 & 10 & 2,250 & 186,439 \\
\hline 4 & 25 & 3,199 & 230,381 \\
\hline 5 & 50 & 3,902 & 262,980 \\
\hline 6 & 100 & 4,600 & 295,339 \\
\hline
\end{tabular}

Sumber: Hasil Perhitungan,2019

Periode Ulang Hujan atau yang disingkat PUH adalah waktu hipotetik dimana hujan dengan suatu besaran tertentu akan disamai atau dilampaui. PUH yang digunakan dalam analisa hidrologi yaitu PUH 2, 5, 10, 25, 50 dan 100 tahun (Hardjosuprapto,1998)

\section{b. Metode Log Pearson Tipe III}

Langkah perhitungan analisa frekuensi dengan metode Log Pearson Tipe III adalah sebagai berikut:
- Mengubah data kedalam bentuk logaritmis

- Hitung nilai rata-rata (R), standar deviasi (S) dan nilai koefisien kemencengan $(G)$. Nilai koefisien $\mathrm{G}$ yang didapat digunakan untuk menentukan nilai $\mathrm{K}$, dengan cara plotting nilai koefisien G kedalam Tabel 7., Nilai K digunakan untuk menghitung curah hujan harian maksimum berdasarkan metode Log Pearson Tipe III.

Tabel 7. Nilai $K$ dengan $G=-0,6$

\begin{tabular}{ccc}
\hline No & T(PUH) & $\mathrm{K}$ \\
\hline 1 & 2 & 0,050 \\
\hline 2 & 5 & 0,853 \\
\hline 3 & 10 & 1,245 \\
\hline 4 & 25 & 1,643 \\
\hline 5 & 50 & 1,890 \\
\hline 6 & 100 & 2,140 \\
\hline Sumber: Hasil Perhitungan,2019
\end{tabular}

- Menghitung logaritma hujan dengan periode ulang hujan menggunakan Persamaan [6] dan menghitung antilog Log RT.

Rekapitulasi hasil perhitungan curah hujan dengan metode Log Pearson Tipe III dapat dilihat pada Tabel 8 .

Tabel 8. Rekapitulasi Curah Hujan Metode Log Pearson

\begin{tabular}{ccccc}
\hline No & PUH & K & Log RT & $\mathrm{R}_{\mathrm{T}}$ \\
\hline 1 & 2 & 0,099 & 1,995 & 98,894 \\
\hline 2 & 5 & 0,857 & 2,180 & 151,199 \\
\hline 3 & 10 & 1,200 & 2,263 & 183,223 \\
\hline 4 & 25 & 1,528 & 2,343 & 220,173 \\
\hline 5 & 50 & 1,72 & 2,389 & 245,169 \\
\hline 6 & 100 & 1,88 & 2,428 & 268,154 \\
\hline
\end{tabular}

Sumber: Hasil Perhitungan,2019

\section{c. Metode Distribusi Normal}

frekuensi $\mathrm{K}_{\mathrm{T}}$ didapatkan pada dari nilai variable Reduksi Gauss yang terdapat pada Tabel 9.

Tabel 9. Reduksi Gauss $\left(\mathrm{K}_{\mathrm{T}}\right)$

\begin{tabular}{ccc}
\hline No & T(PUH) & $\mathrm{K}_{\mathrm{T}}$ \\
\hline 1 & 2 & 0,000 \\
\hline 2 & 5 & 0,840 \\
\hline 3 & 10 & 1,280 \\
\hline 4 & 25 & 1,708 \\
\hline 5 & 50 & 2,050 \\
\hline 6 & 100 & 2,330 \\
\hline
\end{tabular}

Sumber: Suripin,2004

Penentuan nilai curah hujan harian maksimum dihitung dengan menggunakan Persamaan [7]. Rekapitulasi hasil perhitungan metode Distribusi Normal dapat dilihat pada Tabel 10.

Proteksi/Desember 2019 Volume 1 No. 2 
Tabel 10.Rekapitulasi Curah Hujan Metode Distribusi Normal

\begin{tabular}{ccccc}
\hline No & PUH & $\mathbf{K}_{\mathbf{T}}$ & $\mathbf{K}_{\mathbf{T}} \times \mathbf{S}$ & $\mathbf{R}_{\mathbf{T}}$ \\
\hline 1 & 2 & 0,000 & 0,000 & 106,988 \\
\hline 2 & 5 & 0,840 & 43,305 & 150,293 \\
\hline 3 & 10 & 1,280 & 65,989 & 172,976 \\
\hline 4 & 25 & 1,708 & 88,071 & 195,058 \\
\hline 5 & 50 & 2,050 & 105,685 & 212,672 \\
\hline 6 & 100 & 2,330 & 120,120 & 227,107 \\
\hline
\end{tabular}

Sumber: Hasil Perhitungan,2019

Data hasil analisa frekuensi untuk setiap metode kemudian dilakukan uji kecocokan dengan Chikuadrat.Uji chi-kuadrat dimaksudkan untuk menentukan apakah persamaan distribusi yang telah dipilih dapat mewakili distribusi statistik sampel data yang dianalisis. Rekapitulasi hasil perhitungan analisa frekuensi curah hujan setiap metode dapat dilihat pada Tabel 11.

Tabel 11. Rekapitulasi Analisa Frekuensi

\begin{tabular}{ccccc}
\hline No & PUH & Gumbel & $\begin{array}{c}\text { Log Pearson } \\
\text { Tipe III }\end{array}$ & $\begin{array}{c}\text { Distribusi } \\
\text { Normal }\end{array}$ \\
\hline 1 & 2 & 99,133 & 98,894 & 106,988 \\
\hline 2 & 5 & 151,661 & 151,199 & 150,293 \\
\hline 3 & 10 & 186,439 & 183,223 & 172,976 \\
\hline 4 & 25 & 230,381 & 220,173 & 195,058 \\
\hline 5 & 50 & 262,980 & 245,169 & 212,672 \\
\hline 6 & 100 & 295,339 & 268,154 & 227,107 \\
\hline
\end{tabular}

Sumber: Hasil Perhitungan,2019

Hasil uji Chi-kuadrat yang dihitung dibandingkan dengan nilai Chi-kuadrat sebenarnya. Hasil uji ChiKuadrat dapat dilihat pada Tabel 12.

Tabel 12. Nilai Peluang Setiap Metode

\begin{tabular}{ccccc}
\hline Distribusi & $\mathrm{X}^{2}$ Hitung & Peluang & $\mathrm{X}^{2}$ Tabel & Ket \\
\hline Gumbel & 0,667 & $<$ & 5,991 & $\begin{array}{c}\text { Dapat } \\
\text { Diterima }\end{array}$ \\
\hline $\begin{array}{c}\text { Log } \\
\text { Pearson }\end{array}$ & 5,667 & $<$ & 5,991 & $\begin{array}{c}\text { Dapat } \\
\text { Diterima }\end{array}$ \\
\hline $\begin{array}{c}\text { Distribusi } \\
\text { Normal }\end{array}$ & 2,333 & $<$ & 5,991 & $\begin{array}{c}\text { Dapat } \\
\text { Diterima }\end{array}$ \\
\hline
\end{tabular}

Sumber: Hasil Perhitungan,2019

Syarat yang harus dipenuhi yaitu $\mathrm{X}^{2}$ hitung $<\mathrm{X}^{2}$ tabel. Berdasarkan Tabel 12, ketiga metode tersebut dapat memenuhi syarat karena memiliki nilai $\mathrm{X}^{2}$ hitungyang lebih kecil 5,99. Metode yang dipilih adalah metode Gumble karena memiliki nilai $\mathrm{X}^{2}$ (hitung) yang paling kecil jika dibandingkan dengan metode lain dan nilai frekuensi curah hujan yang paling besar diantara ketiga metode.

Hasil uji kecocokan dengan Chi-kuadrat kemudian dilakukan analisis intensitas hujan dengan metode Van Breen, Bell Tanimoto, dan Hasper Der Weduwen.

\section{Analisis Intensitas Hujan}

Metode Gumbel merupakan data awal yang digunakan dalam tahap analisis intensitas hujan dapat dilihat pada Tabel 6.Terdapat 3 (tiga) metode yang dapat dilakukan dalam melakukan analisis intensitas hujan, yaitu:

\section{a. Metode Van Breen}

Hasil perhitungan intensitas hujan dengan Metode Van Breen dapat dilihat pada Tabel 13.

Tabel 13. Intensitas Curah Hujan Metode Van Breen

\begin{tabular}{cccccccc}
\hline \multirow{2}{*}{ Durasi } & \multicolumn{7}{c}{ Intensitas Curah Hujan (mm/jam) } \\
\cline { 2 - 8 } & 2 & 5 & 10 & 25 & 50 & 100 \\
\cline { 2 - 8 } & $\mathrm{R} 1$ & $\mathrm{R} 2$ & $\mathrm{R} 3$ & $\mathrm{R} 4$ & $\mathrm{R} 5$ & $\mathrm{R} 6$ \\
\hline 5 & 173,89 & 194,06 & 205,16 & 217,99 & 226,98 & 23562 \\
\hline 10 & 152,02 & 176,58 & 189,60 & 204,21 & 214,21 & 223,67 \\
\hline 20 & 121,45 & 149,62 & 164,63 & 181,29 & 192,55 & 203,07 \\
\hline 40 & 86,62 & 114,62 & 130,31 & 148,06 & 160,16 & 171,49 \\
\hline 60 & 67,32 & 92,89 & 107,83 & 125,13 & 137,10 & 148,41 \\
\hline 80 & 55,05 & 78,09 & 91,96 & 108,35 & 119,84 & 130,81 \\
\hline 120 & 40,34 & 59,21 & 71,06 & 85,43 & 95,74 & 105,72 \\
\hline 240 & 22,40 & 34,33 & 42,24 & 52,27 & 59,71 & 67,11 \\
\hline Sumber: & Hasil Perhitungan & 2019 & & &
\end{tabular}

Sumber: Hasil Perhitungan,2019

\section{b. Metode Bell Tanimoto}

Perhitungan intensitas curah hujan berdasarkan metode Bell Tanimoto menggunakan Persamaan [10]. Namun sebelum menentukan nilai intensitas hujan, dihitung nilai curah hujan selama 60 menit dengan periode ulang 10 tahun menggunakan Persamaan [9]. Hasil perhitungan intensitas hujan Metode Bell Tanimoto dapat dilihat pada Tabel 14.

Tabel 14. Intensitas Hujan Metode Bell Tanimoto

\begin{tabular}{|c|c|c|c|c|c|c|}
\hline \multirow{3}{*}{ Durasi } & \multicolumn{6}{|c|}{ Intensitas Curah Hujan (mm/jam) } \\
\hline & 2 & 5 & 10 & 25 & 50 & 100 \\
\hline & R1 & R2 & R3 & R4 & R5 & R6 \\
\hline 5 & 82,34 & 148,28 & 233,51 & 343,87 & 440,30 & 548,13 \\
\hline 10 & 61,63 & 110,98 & 174,77 & 257,36 & 329,54 & 410,24 \\
\hline 20 & 42,98 & 77,39 & 121,88 & 179,48 & 229,81 & 286,09 \\
\hline 40 & 28,72 & 51,72 & 81,45 & 119,94 & 153,58 & 191,19 \\
\hline 60 & 22,38 & 40,30 & 63,47 & 93,46 & 119,67 & 148,98 \\
\hline 80 & 18,66 & 33,60 & 52,92 & 77,93 & 99,79 & 124,22 \\
\hline 120 & 14,36 & 25,86 & 40,73 & 59,98 & 76,80 & 95,61 \\
\hline 240 & 9,07 & 16,33 & 25,72 & 37,87 & 48,49 & 60,36 \\
\hline
\end{tabular}

Sumber: Hasil Perhitungan,2019 


\section{c. Metode Hasper Der Weduwen}

Nilai curah hujan dengan Metode Hasper Der Weduwen ditentukan dengan oleh durasi hujan dalam satuan jam.Perhitungan curah hujan berdasarkan Metode Hasper Der Weduwenjika durasi hujan $1<\mathrm{t}<24$ menggunakan Persamaan [12], dan jika durasi hujan $0<\mathrm{t}<1$ menggunakan Persamaan [13]. Penentuan intensitas hujan dihitung dengan menggunakan Persamaan [14]. Hasil perhitungan intensitas hujan Metode Hasper Der Weduwen dapat dilihat pada Tabel 15.

Tabel 15. Intensitas Hujan Metode Hasper Der Weduwen

\begin{tabular}{ccccccc}
\hline \multirow{2}{*}{ Durasi } & \multicolumn{6}{c}{ Intensitas Curah Hujan (mm/jam) } \\
\cline { 2 - 7 } & 2 & 5 & 10 & 25 & 50 & 100 \\
\cline { 2 - 7 } & $\mathrm{R} 1$ & $\mathrm{R} 2$ & $\mathrm{R} 3$ & $\mathrm{R} 4$ & $\mathrm{R} 5$ & $\mathrm{R} 6$ \\
\hline 5 & 161,10 & 198,03 & 215,41 & 232,38 & 242,42 & 250,81 \\
\hline 10 & 124,20 & 165,44 & 187,33 & 210,50 & 225,15 & 237,97 \\
\hline 20 & 92,19 & 131,63 & 154,98 & 181,79 & 199,99 & 216,79 \\
\hline 40 & 65,19 & 97,79 & 118,69 & 144,34 & 162,85 & 180,80 \\
\hline 60 & 51,92 & 79,43 & 97,64 & 120,65 & 137,73 & 154,67 \\
\hline 80 & 43,25 & 66,16 & 81,33 & 100,50 & 114,72 & 128,84 \\
\hline 120 & 32,93 & 50,38 & 61,93 & 76,53 & 87,36 & 98,11 \\
\hline 240 & 19,75 & 30,21 & 37,14 & 45,89 & 52,38 & 58,83 \\
\hline Sumber: Hasil Perhitungan 2019 & & &
\end{tabular}

Sumber: Hasil Perhitungan,2019

\section{Pemilihan Metode}

Penentuan metode perhitungan intensitas hujan menggunakan persamaan yang sederhana yang umum digunakan, yaitu persamaan Talbot, Sherman, dan Ishiguro. Nilai Intensitas hujan dari analisa curah hujan kemudian disubstitusikan kedalam rumus Talbot, Sherman, dan Ishiguro dengan metode kuadrat terkecil. Persamaan menurut Talbot, Sherman dan Ishiguro dari setiap rumus Van Breen, Bell Tanimoto, dan Hasper Der Weduwen yang didapatkan kemudian disubstitusikan kembali harga-harga durasi ( $\mathrm{t}$ ) nya lalu dibandingkan dengan harga Intensitas hujan hasil analisa. Berikut persamaan-persamaan yang digunakan:

a. Persamaan Talbot

Penentuan intensitas hujan dihitung dengan menggunakan Persamaan [15], konstanta a dan b didapatkan dari Persamaan [16] dan [17].

b. Persamaan Sherman

Penentuan intensitas hujan dihitung dengan menggunakan Persamaan [18], konstanta ndidapatkan dari Persamaan [19].

c. Persamaan Ishiguro
Penentuan intensitas hujan dihitung dengan menggunakan Persamaan [21], konstanta a dan b didapatkan dari Persamaan [22] dan [23].

Penentuan metode terpilih didasarkan pada perbandingan antara data yang terukur dengan perkiraan yang menghasilkan nilai deviasi. Metode dengan nilai deviasi terkecil yang dipilih. Rekapitulasi hasil perhitungan nilai deviasi dengan metode Van Breen dapat dilihat pada Tabel 16.

Tabel 16. Rekapitulasi Deviasi Metode Van Breen

\begin{tabular}{cccc}
\hline \multirow{2}{*}{ PUH } & \multicolumn{3}{c}{ Metode Van Breen } \\
\cline { 2 - 4 } & Talbot & Sherman & Ishiguro \\
\hline 2 & 0,000 & 1,365 & 2,172 \\
\hline 5 & 0,000 & 0,896 & 1,914 \\
\hline 10 & 0,000 & 0,628 & 1,778 \\
\hline 25 & 0,000 & 0,352 & 1,633 \\
\hline 50 & 0,000 & 0,186 & 1,541 \\
\hline 100 & 0,000 & 0,050 & 1,459 \\
\hline
\end{tabular}

Sumber: Hasil Perhitungan,2019

Hasil perhitungan dengan metode Bell Tanimoto dapat dilihat pada Tabel 17

Tabel 17.Rekapitulasi Deviasi Metode Bell Tanimoto

\begin{tabular}{cccc}
\hline \multirow{2}{*}{ PUH } & \multicolumn{3}{c}{ Metode Bell Tanimoto } \\
\cline { 2 - 4 } & Talbot & Sherman & Ishiguro \\
\hline 2 & 73,123 & 0,327 & 57,040 \\
\hline 5 & 0,475 & 0,590 & 0,378 \\
\hline 10 & 0,748 & 0,929 & 0,595 \\
\hline 25 & 1,102 & 1,367 & 0,876 \\
\hline 50 & 1,410 & 1,751 & 1,121 \\
\hline 100 & 1,756 & 2,180 & 1,396 \\
\hline
\end{tabular}

Sumber: Hasil Perhitungan,2019

Hasil perhitungan dengan metode Haspe Der Weduwen dapat dilihat pada Tabel 18.

Tabel 18. Rekapitulasi Deviasi Metode Hasper Der Weduwen

\begin{tabular}{cccc}
\hline \multirow{2}{*}{ PUH } & \multicolumn{3}{c}{ Metode Hasper Der Weduwen } \\
\cline { 2 - 4 } & Talbot & Sherman & Ishiguro \\
\hline 2 & 21,246 & 0,883 & 0,496 \\
\hline 5 & 0,162 & 1,090 & 0,964 \\
\hline 10 & 0,063 & 1,040 & 1,374 \\
\hline 25 & 0,012 & 0,802 & 2,030 \\
\hline 50 & 0,043 & 0,521 & 2,638 \\
\hline 100 & 0,145 & 0,172 & 3,365 \\
\hline
\end{tabular}

Sumber: Hasil Perhitungan,2019

Berdasarkan Tabel 16, Tabel 17, dan Tabel 18 metode yang memiliki deviasi terkecil yaitu Metode Van Breen dengan Persamaan Talbot, sehingga intensitas hujan yang digunakan dalam perencanaan 
adalah intensitas hujan dengan Metode Van Breen dan Persamaan Talbot. Hasil perhitungan intensitas tersebut dapat dilihat pada Tabel 19.

Tabel 19. Intensitas Hujan Metode Van Breen dengan Persamaan Talbot

\begin{tabular}{cccccccc}
\hline \multirow{2}{*}{ Durasi } & \multicolumn{6}{c}{ Intensitas Curah Hujan (mm/jam) } \\
\cline { 2 - 8 } & 2 & 5 & 10 & 25 & 50 & 100 \\
\hline 5 & 173,89 & 194,06 & 205,16 & 217,99 & 226,98 & 235,62 \\
\hline 10 & 152,02 & 176,58 & 189,60 & 204,21 & 214,21 & 223,67 \\
\hline 20 & 121,45 & 149,62 & 164,63 & 181,29 & 192,55 & 203,07 \\
\hline 40 & 86,62 & 114,62 & 130,31 & 148,06 & 160,16 & 171,49 \\
\hline 60 & 67,32 & 92,89 & 107,83 & 125,13 & 137,10 & 148,41 \\
\hline 80 & 55,05 & 78,09 & 91,96 & 108,35 & 119,84 & 130,81 \\
\hline 120 & 40,34 & 59,21 & 71,06 & 85,43 & 95,74 & 105,72 \\
\hline 240 & 22,40 & 34,33 & 42,24 & 52,27 & 59,71 & 67,11 \\
\hline
\end{tabular}

Sumber: Hasil Perhitungan,2019

Berdasarkan Tabel 19., nilai intensitas hujan dihitung pada durasi $5,10,20,40,60,80,120$ dan 240 menit. Nilai intensitas hujan pada PUH 2 tahun berada pada rentang $22,40-173,89 \mathrm{~mm} / \mathrm{jam}$, pada PUH 5 tahun berada pada rentang 34,33-194,06 $\mathrm{mm} / \mathrm{jam}$, pada PUH 10 tahunberada pada rentang 42,24-205,16 mm/jam, pada PUH 25 tahun berada pada rentang 52,27-217,99 $\mathrm{mm} / \mathrm{jam}$, pada PUH 50 tahun berada pada rentang 59,71-226,98 mm/jam dan pada PUH 100 tahun berada pada rentang $67,11-235,62 \mathrm{~mm} / \mathrm{jam}$.

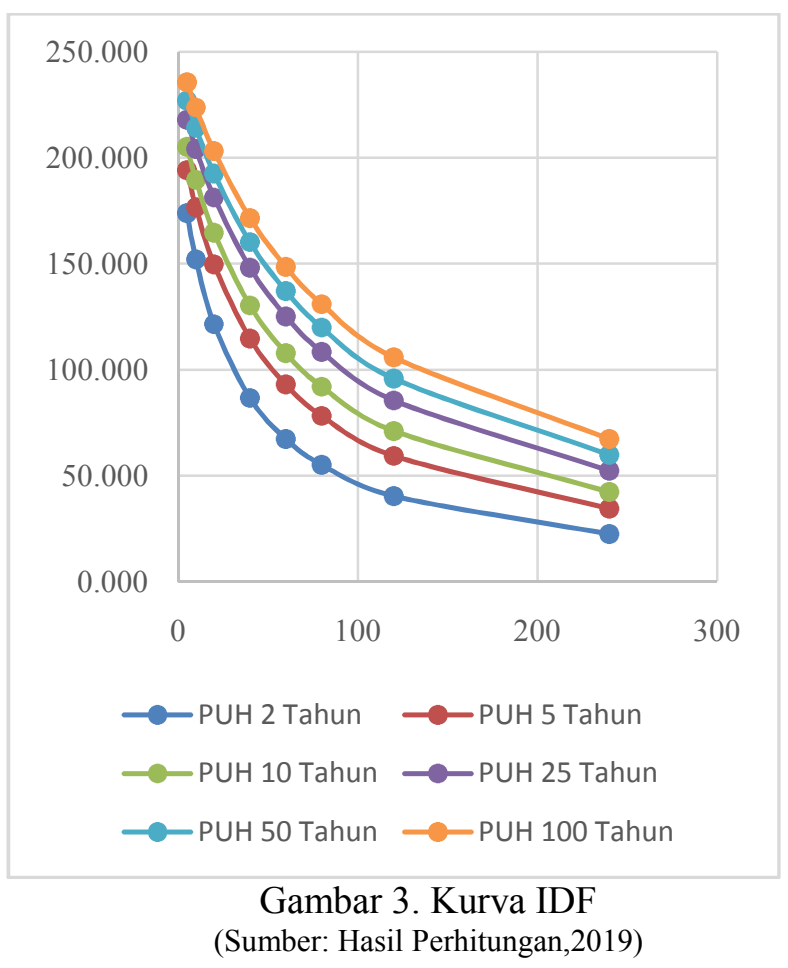

\section{SIMPULAN}

Hasil perhitungan menunjukkan bahwa metode intensitas hujan yang terpilih adalah Metode van
Breen dengan Persamaan Talbot, untuk PUH 2 tahun nilai intensitas hujan berada pada rentang 22,40-173,89 $\mathrm{mm} / \mathrm{jam}$, pada PUH 5 tahun berada pada rentang 34,33-194,06 mm/jam, pada PUH 10 tahunberada pada rentang 42,24-205,16 mm/jam, pada PUH 25 tahun berada pada rentang 52,27$217,99 \mathrm{~mm} / \mathrm{jam}$, pada PUH 50 tahun berada pada rentang 59,71-226,98 mm/jam dan pada PUH 100 tahun berada pada rentang 67,11-235,62 mm/jam. Nilai intensitas hujan metode terpilih digunakan untuk menentukan debit banjir rencana dan penentuan dimensi saluran di Aerocity X.

\section{REFERENSI}

Suripin, 2004, "Sistem Drainase Perkotaan yang Berkelanjutan"Yogyakarta: Andi Yogyakarta. Hardjosuprapto, M.,1998, "Drainase Perkotaan, Volume 2", Bandung: Penerbit ITB.

Melinda, N. ,2007, "Perencanaan Sistem Drainase Pada Daerah Aliran Sungai Cimahi di Kota Cimahi" Skripsi, Fakultas Teknik Sipil dan Lingkungan, Institut Teknologi Bandung.

Triatmodjo Bambang, 2008, "Hidrologi Terapan", Beta Offset, Yogyakarta.

Soewarno, 1995,"Hidrologi Aplikasi Metode Statistik Untuk Analisa Data", Penerbit Nova, Bandung.

Hardjosuprapto, M. ,1998,"Drainase Perkotaan, Volume 1" Bandung: Penerbit ITB.

Subarkah, Imam, 1980,'Hidrologi Untuk Perencanaan Bangunan Air", Penerbit Idea Dharma, Bandung.

Ardi Riyo., Indriana Dyah., dkk. ,2015, “Analisa Hidrologi Dan Hidrolika Saluran Drainase Box Culvert di Jalan Antasari Bandar Lampung Menggunakan Program HECRAS” Skripsi, Fakultas Teknik Sipil, Universitas Lampung

Nihayatin, Laili Zaidiyah dan Sutikno, 2013, "Perbandingan Uji Homogenitas Runtun Data Curah Hujan Sebagai Pra-Pemrosesan Kajian Perubahan Iklim" , Skripsi, Fakultas Matematika, Institut Teknologi Sepuluh November

Halaludin dan Joko Santoso, 2001, "perencanaan dam dan spillway yang dilengkapi PLTMH di Kampus Tembalang" , Tugas Akhir, Universitas Diponegoro 